\title{
CUSTOMER RELATIONSHIP MANAGEMENT (CRM) DAN APLIKASINYA DALAM INDUSTRI MANUFAKTUR DAN JASA
}

\author{
Edwin Agung Wibowo \\ Fakultas Ekonomi, Universitas Riau Kepulauan Batam
}

\begin{abstract}
Customer Relationship Management (CRM) is one of the ways to maintain continuous relationship between a company and its stakeholders as well as its shareholder. A lot of companies are using CRM to maintain its relationship with the customers. By using CRM, the companies will be able to find out their customers' needs and wants so that emotionally they can be involved with each other. This enables them to have a two-way communication. As a result, they will have close and open business relationship which makes the customers, especially, loyal to the companies; and they will not easily change their preference to another product or brand.
\end{abstract}

Keywords: customer relationship management, business relationship, communication, customer loyalty.

\section{PENDAHULUAN}

Sekarang ini banyak perusahaan yang menggunakan berbagai sarana dalam usahanya untuk meningkatkan Customer Relationship Management (CRM). Secara khusus mereka berusaha memberikan layanan yang sifatnya personal sehingga dapat memberikan kepuasan yang tinggi pada pelanggannya, baik sebagai stakeholder maupun shareholder. Dengan demikian diharapkan akan terjalin value chain yang kuat di antara mereka melalui customer relationship (hubungan dengan pelanggan).

Untuk dapat meningkatkan CRM, perusahaan tidak segan melakukan investasi yang cukup mahal dan teknologi canggih yang mampu memberikan layanan yang maksimal bagi pelanggan. Di sisi lain banyak perusahaan software yang menjual dan menawarkan aplikasi sistem ini Web applications seperti e-mail marketing dan the dot-coms.

Menurut Costanzo (2003, p.8), CRM merujuk pada software system yang membantu perusahaan memperoleh dan menyimpan data pelanggannya serta melakukan hubungan dua arah. Tetapi saat ini CRM lebih menekankan pada perubahan kebijakan dan prosedur yang didesain untuk meningkatkan sales dan customer retention di berbagai lini perusahaan. Oleh karena itu dalam tulisan ini penulis akan membahas apa yang dimaksud dengan CRM dan tujuannya, mengapa 
perusahaan perlu CRM, aplikasi CRM dalam industri manufaktur dan jasa serta kesimpulan yang dapat ditarik dari pembahasan CRM ini.

\section{CRM DAN TUJUANNYA}

"Customer Relationship Management, or CRM, is a business strategy designed to improve profitability, revenue, and customer satisfaction. It consists of software, services, and a new way of thinking to improve profitability, revenue, and customer satisfaction. How? By helping organizations of every size identify the right customers, acquire more of the right customers faster, and retain the right customers longer." <http://www.aspective.com/

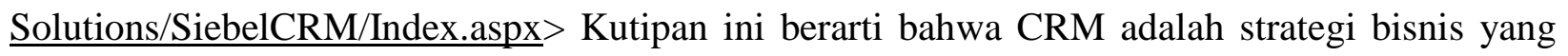
terdiri dari software dan layanan yang didesain untuk meningkatkan keuntungan (profit), pendapatan (revenue) dan kepuasan pelanggan (customer satisfaction). Caranya adalah dengan membantu berbagai bentuk perusahaan untuk mengidentifikasi pelanggannya dengan tepat, memperoleh lebih banyak pelanggan dengan lebih cepat, dan mempertahankan kesetiaan pelanggannya.

Selanjutnya Martin, Brown, DeHayes, Hoffer \& Perkins (2005, p.194) menambahkan “ $A$ CRM system attempts to provide an integrated approach to all aspects of interaction a company has with its customers, including marketing, sales and support. The goal of a CRM system is to use technology to forge a strong relationship between a business and its customers. To look at CRM in another way, the business is seeking to better manage its own enterprise around customer behaviors”. Kutipan ini menyatakan bahwa sistem CRM berusaha menyediakan sebuah pendekatan terintegrasi terhadap semua aspek dalam perusahaan dalam kaitannya dengan pelanggannya, yang meliputi marketing, sales and support. Tujuan dari sistem ini adalah dengan penggunaan teknologi diharapkan terjadi jalinan hubungan yang kuat antara perusahaan dengan pelanggannya. Dengan kata lain, perusahaan berusaha mengelola kinerja perusahaannya dengan lebih baik.

Menurut O’Brien (2002, p.130), “CRM uses information technology to create a cross-functional enterprise system that integrates and automates many of the customer serving processes in sales, marketing, and product services that interact with a company's customers. CRM systems also create an IT framework that integrates all of these processes with the rest of a company's business operations. CRM systems consist of a family of software modules that perform the business activities involved in 
such front office processes. CRM software provides the tools that enable a business and its employees to provide fast, convenient, dependable, and consistent service to its customers." Kutipan ini berarti bahwa CRM menggunakan teknologi informasi untuk menciptakan cross-functional enterprise system yang mengintegrasikan dan mengotomatisasi proses layanan pelanggan dalam bidang penjualan, pemasaran, dan layanan produk/ jasa berkaitan dengan perusahaan. Sistem CRM juga menciptakan IT framework yang menghubungkan semua proses dengan bisnis operasional perusahaan. Selain itu sistem CRM juga meliputi sekumpulan modul software yang membantu aktivitas bisnis perusahaan, seperti proses kantor depan. Software CRM adalah sebuah alat yang memungkinkan perusahaan untuk memberikan layanan yang cepat, prima serta konsisten pada pelanggannya dan dapat digambarkan sebagai berikut:

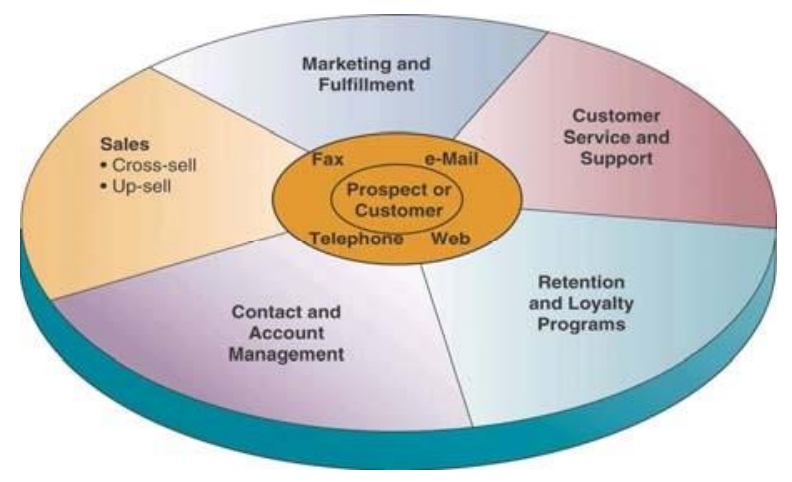

Sumber: O’Brien (2002,p.130)

\section{Gambar 1. Sistem CRM dalam Proses Bisnis}

Banyak paket software diciptakan untuk memudahkan customer relationship, tetapi kebanyakan tergantung dari perolehan, updating dan utilisasi profil individu pelanggan. Profil-profil pelanggan ini biasanya disimpan dalam data warehouse, dan data mining digunakan untuk mengekstrasi informasi yang berhubungan dengan perusahaan dari pelanggan yang bersangkutan. Selanjutnya profil pelanggan ini terhubung secara on line sehingga mereka yang bekerja dalam perusahaan itu dapat menghubungi pelanggan yang bersangkutan. Selain itu Webbased front-ends telah diciptakan sehingga pelanggan dapat menghubungi perusahaan secara online untuk memperoleh informasi mengenai produk atau jasa yang ditawarkan oleh perusahaan itu, memesan order, mengecek status order yang ada, memperoleh jawaban atas pertanyaan yang diajukan atau untuk memperoleh layanan. Paket software CRM membantu perusahaan untuk 
memasarkan, menjual, dan melayani pelanggan melalui multi media, termasuk Web, call centers, field representatives, business partners, retail and dealer networks.

Program CRM dalam penerapannya dapat dilihat seperti gambar berikut ini:

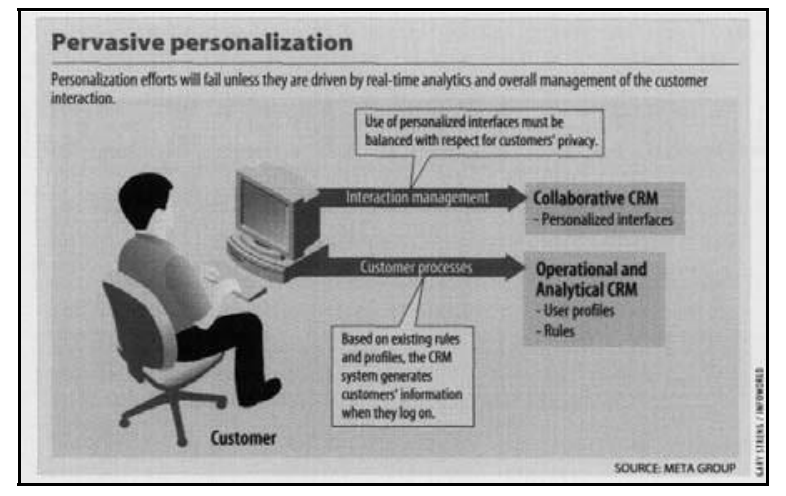

Sumber: Jones (2001,p.30)

\section{Gambar 2. Sistem Berbasis IT}

Dari definisi-definisi sebelumnya dapat dikatakan bahwa CRM adalah serangkaian pendekatan dan sistem yang berbasis teknologi informasi (IT-Based System) yang berguna untuk menjalin hubungan bisnis yang lebih erat dan terbuka serta memungkinkan adanya komunikasi dua arah antara perusahaan dengan pelanggannya, baik sebagai stakeholder maupun shareholder.

\section{KEBUTUHAN CRM}

O’Brien (2002, pp.130-1) menegaskan bahwa CRM memungkinkan perusahaan mengidentifikasi dan membidik pelanggan terbaiknya, yaitu mereka yang menguntungkan perusahaan, sehingga mereka dapat dipertahankan menjadi pelanggan yang setia untuk jangka panjang. Mereka diharapkan akan memberikan keuntungan yang lebih besar bagi perusahaan. Selain itu, CRM memungkinkan realtime customization and personalization atas produk dan jasa berdasarkan keinginan, kebutuhan, kebiasaan pembelian dan siklus kehidupan pelanggannya. CRM juga memantau data pelanggannya setiap kali dia melakukan kontak dengan perusahaan. CRM memungkinkan perusahaan untuk menyediakan layanan dan dukungan yang konsisten dan prima terhadap semua kontak yang diinginkan pelanggannya sehingga pelanggan memperoleh pengalaman yang menyenangkan. Semua keuntungan ini memberikan nilai bisnis yang strategis bagi perusahaan sekaligus perceived value bagi pelanggannya.

CRM meliputi sentralisasi semua data pelanggan perusahaan dan otomatisasi kegiatan mengelola sales, marketing, dan customer service yang membosankan sehingga para profesional 
dapat menggunakan waktunya untuk melayani pelanggannya secara lebih efektif dan efisien terutama dalam melakukan kegiatan administrasinya. Sejak ditemukannya 12 tahun lalu, CRM terbukti telah membantu perusahaan untuk melakukan transaksi lebih cepat, membantu dalam menentukan segmentasi dan mencapai target pelanggannya lebih baik, serta meningkatkan customer satisfaction and loyalty secara dramatis dengan memberikan layanan yang prima <http://www. aspective.com/Solutions/SiebelCRM/Index.aspx>.

Keuntungan CRM sudah jelas yaitu dapat mempercepat proses dan memberikan kemudahan bagian sales, marketing dan service personnel dengan informasi pelanggan yang lebih baik dan lengkap. CRM memberi kemudahan pada perusahaan untuk membangun customer relationship dan mengurangi biaya operasional.

Di bagian sales, otomatisasi proses penjualan dapat menjadi sangat sederhana. CRM membantu mengurangi siklus penjualan dengan adanya informasi pelanggan yang relevan dan tersedia setiap saat sehingga memungkinkan pekerjaan menjadi lebih efisien. Proses otomatisasi ini juga memungkinkan pihak manajemen untuk mengecek kinerja timnya secara real time dan mengetahui siapa yang benar-benar sedang bekerja dan siapa yang tidak bekerja. Dengan informasi ini, pihak manajemen dapat menyesuaikan alir proses penjualan ke dalam sistem untuk mengurangi bottleneck sehingga diperoleh perkiraan pendapatan dan siklus penjualan yang lebih tepat <http://www.aspective.com/ Solutions/SiebelCRM/Index.aspx>.

Dengan adanya otomatisasi fungsi-fungsi marketing seperti campaign design and management, email marketing, lead assignment and management, perusahaan dapat meningkatkan efisiensi dan efektivitas bagian marketing. Otomatisasi ini dapat membidik pelanggan potensial, sumber daya utama dan informasi geografis yang membantu siklus penjualan. Pihak manajemen dapat memahami program-program yang diciptakan untuk meningkatkan pendapatan secara maksimal. Dengan demikian, manajemen dapat mengetahui program marketing mana yang paling efektif dan mana yang perlu ditingkatkan untuk membidik investasi marketing secara lebih sukses dengan cara mengidentifikasikan new markets dan opportunities, menyederhanakan proses marketing, mengkuantifikasi ROI biaya marketing, dan meningkatkan produktifitas marketing dengan mengurangi acquisition costs <http://www. aspective.com/Solutions/SiebelCRM/Index.aspx>. 
Customer service dan call center operations dapat menggunakan CRM untuk membantu para staff dengan informasi yang terbaru dan up-to-date dari semua transaksi yang terjadi di bagian ini. Dengan otomatisasi service request management, knowledge bases dan call routing, para staff dapat menjadi lebih produktif dengan memastikan bahwa semua permintaan layanan pelanggan dapat dijawab dan setiap masalah pelanggan dapat diselesaikan dengan baik secara lebih cepat. Karena para staff memperoleh akses langsung atas customer records, maka mereka dapat mengantisipasi setiap peluang/ masalah yang ada untuk memperoleh solusi layanan. Sebagai imbalannya, pelanggan akan memperoleh layanan yang prima sehingga meningkatkan customer retention and loyalty <http://www.aspective.com/Solutions/SiebelCRM/Index.aspx>. CRM dapat dijelaskan melalui gambar berikut ini:

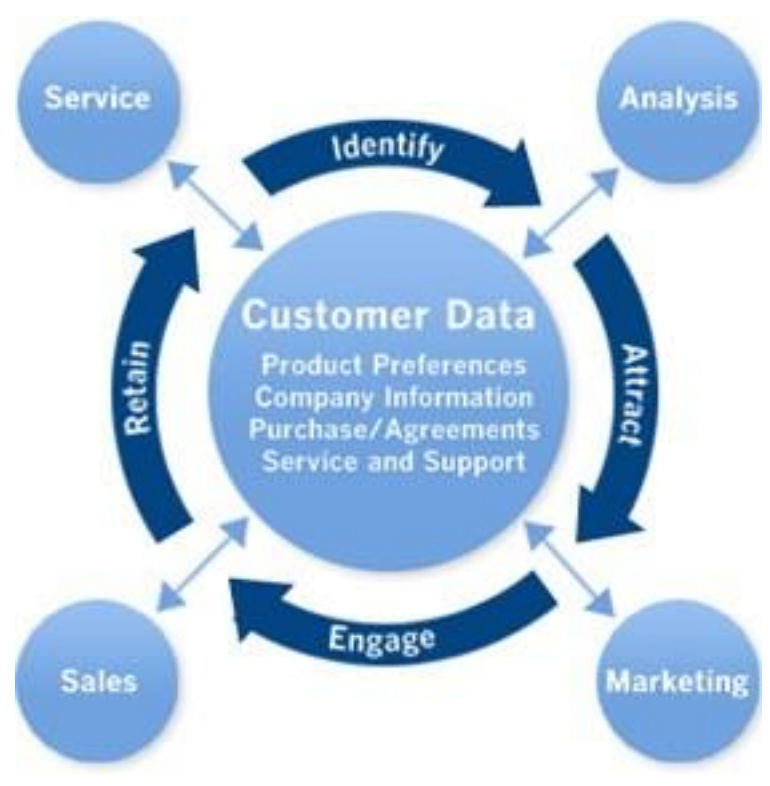

Sumber: 〈http://www.aspective.com/Solutions/SiebelCRM/ Index.aspx>

\section{Gambar 3. Alur Aktivitas Bisnis dengan Database CRM}

Tyler (2005,p.50) juga menegaskan hal yang sama bahwa dengan menggunakan database CRM dalam bisnis akan pembantu perusahaan untuk mengetahui alir seluruh aktivitas mulai panggilan telpon untuk order penjualan hingga permintaan layanan. Dengan adanya sentralisasi semua komunikasi yang terjadi dengan pelanggan pada suatu tempat akan meningkatkan efisiensi. Ketika ada konsistensi maka akan terbentuk kemampuan untuk mengukur dan mengelola sumber daya manusia dan semua proses yang terjadi. 
Dalam risetnya, Freeman \& Seddon menyatakan ada keuntungan yang didapat perusahaan dengan penerapan CRM ini. Pertama, perusahaan dapat meningkatkan proses komunikasi dua arah dengan pelanggan sehingga proses transaksi menjadi lebih cepat dan akurat, pengurangan cycle time, dan headcount reduction. Kedua, perusahaan dapat meningkatkan management decisions dan profit. Ketiga, customer service dapat ditingkatkan layanannya. Yang terakhir, perusahaan dapat meningkatkan business growth and support <http://csrc.lse.ac.uk/ asp/aspecis/20050161.pdf >.

\section{APLIKASI CRM DALAM INDUSTRI MANUFAKTUR DAN JASA}

Banyak perusahaan di dunia yang menerapkan CRM sejak pertama kali ditemukan. Salah satunya adalah Eli Lilly \& Company, sebuah perusahaan farmasi yang mengimplementasikan penggunaan sales-force automation, call center dan beberapa aplikasi software dari Siebel untuk mendukung usahanya dalam rangka memperkenalkan merek produk obat yang dipasarkan. Menurut Roy Dunbar, Chief Information Officer perusahaan Eli Lilly \& Company, pasien yang pernah menggunakan mereknya dulu terbiasa menghubungi dokter pribadinya. Tetapi sekarang ia dapat menghubungi perusahaan melalui telpon untuk memperoleh informasi lebih lanjut mengenai produk dan merek produknya. Dengan adanya sistem CRM, Lilly memanfaatkan layanan call center untuk menjalin hubungan yang lebih erat dengan pelanggannya (Martin, Brown, DeHayes, Hoffer \& Perkins, 2005, p. 196).

Penerapan CRM dalam perusahaan farmasi juga mampu mendongkrak penjualan dan meningkatkan hubungan dengan relasi yang paling dasar. Dengan CRM, perusahaan obat-obatan akan mampu mengidentifikasi dokter mana yang proaktif dengan tenaga pemasarnya, mengkalkulasi pendapatan potensial yang diperoleh dari hubungannya dengan para dokter tersebut, menjalin hubungan yang lebih erat dengan para dokter yang merekomendasikan obatnya kepada pasien. Kos Pharmaceutical Inc., sebuah perusahaan farmasi yang memproduksi obat untuk penyakit jantung koroner dan paru-paru, telah mengimplementasikan CRM pada 2003 dengan 500 tenaga pemasarannya. Staff pemasarannya bertumbuh dan mempunyai komunikasi yang lebih baik antara mereka, khususnya ketika mereka mengunjungi dokter yang sama. Para dokter merasa nyaman karena ternyata tenaga pemasaran yang berbeda ini mampu memberikan informasi yang berkesinambungan (Martin, Brown, DeHayes, Hoffer \& Perkins, 2005, p. 196). 
Lebih lanjut, menurut Martin, Brown, DeHayes, Hoffer \& Perkins (2005, p. 196), perusahaan komputer Hewlett-Packard (HP) menerapkan bermacammacam software CRM secara besar-besaran pada semua saluran distribusi perusahaannya dengan menggunakan eBusiness Applications package dari Siebel Systems, Inc. Sistem ini mampu mengkonsolidasikan saluran distribusi penjualannya secara langsung maupun tak langsung, termasuk ribuan direct-sales representatives, marketing professionals, contact-center representatives, partner resellers. Proyek ini mampu mengintegrasikan 50.000 pengguna sistem. Hewlett-Packard berharap mampu memperoleh keuntungan yang berlipat ganda dari berbagai saluran distribusinya dengan adanya sistem ini sehingga mampu meningkatkan efisiensi operasionalnya, menghemat puluhan juta dolar (Dunn, 2003). HP juga memanfaatkan CRM database dengan mengirimkan customized e-newsletter kepada para pelanggannya untuk menginformasikan produkproduk terbarunya dan memberikan solusi atas pertanyaan-pertanyaan mengenai layanan yang sering diajukan oleh pelanggannya. Newsletter ini ternyata mampu meningkatkan penjualan produk baru HP serta mengurangi panggilan telpon ke service center. Program email yang efektif mampu memberikan informasi yang berguna dan diperlukan dengan tepat waktu (Cannon, Perreault \& McCarthy, 2008, p. 379).

Cannon, Perreault \& McCarthy (2008, p. 379), menyatakan bahwa database CRM juga berguna bagi pelanggan perusahaan. Sebagai contoh, Forrester Reasearch melakukan riset pasar terhadap bermacammacam industry dan kemudian menjual hasil riset pasarnya kepada publik. Pelanggan yang mengakses website Forrester dan menginginkan industri dan topik yang dipilih dapat mendaftar. Selanjutnya Forrester akan mengirimkan email secara reguler dengan data yang diperbarui seperti yang pelanggan inginkan.

Perusahaan-perusahaan lain di dunia yang menerapkan CRM antara lain Audi AG, sebuah perusahaan otomotif di Jerman. Selain itu ada Brother International, sebuah perusahaan elektronik milik Jepang, yang berbasis di Amerika dengan 1.200 karyawan dan memperoleh pendapatan lebih dari US\$ 1 milyar. Berikutnya adalah Adidas Salomon AG yang merupakan perusahaan yang memproduksi peralatan dan perlengkapan olah raga dengan 14.700 karyawan dan pendapatan sekitar 6,5 milyar Euro 〈http://csrc.lse.ac.uk/asp/aspecis/20050161.pdf 〉.

Dengan CRM, perusahaan mampu meningkatkan usaha pemasaran dengan memanfaatkan database yang ada, termasuk produk atau jasa yang pernah dibeli oleh pelanggan sebelumnya dan informasi mengenai segmentasi pasar lainnya. Sebuah perusahaan jasa reparasi 
mobil, misalnya, akan menyimpan database mengenai penggantian oli pelanggannya. Berdasarkan data ini, perusahaan dapat mengirimkan postcard untuk mengingatkan kapan waktunya pelanggan melakukan pergantian oli kendaraan berikutnya. Demikian juga seorang penjual bunga dapat menggunakan database pelanggannya untuk menelpon dan memberikan tawaran khusus (special offer) atas produknya untuk Mother's Day atau Valentine's Day. Perusahaan yang memanfaatkan internet untuk kegiatan operasionalnya memperoleh keuntungan tersendiri dengan pendekatan database ini. Mereka mampu berkomunikasi dengan pelanggannya melalui website atau email; dan ini berarti bahwa keseluruhan usaha yang dilakukan bukan hanya untuk membidik target tertentu tetapi juga karena beayanya sangat murah. Selain itu, pelanggan juga mudah menjawab dan merespon dengan mudah dan cepat. Amazon.com juga memanfaatkan CRM. Ketika seorang pelanggan hendak memesan buku, sistem CRM Amazon.com pada website-nya merekomendasikan buku-buku terkait yang pernah dibeli oleh pelanggan-pelanggan lainnya (Cannon, Perreault, McCarthy, 2008, pp.80-1).

Hong Kong's Mevas Bank, sebuah perusahaan perbankan di Hong Kong juga menerapkan CRM. Ketika pertama kali menerapkan CRM, Bank ini tidak mempunyai sebuah cabangpun. Pelanggan hanya dapat melakukan transaksi secara on line melalui website. Staff Bank berada di tempat untuk menjawab pertanyaan melalui website dan melayani permintaan investasi secara on line. Web sebagai media bagi nasabah untuk melakukan berbagai transaksi (personal banking tools), sedangkan Mevas Bank hanyalah sebagai tempat bertatap muka. Menurut Bernard Kwok, kepala bagian customer service, pendekatan elektronik yang radikal ini menurunkan biaya operasional dam meningkatkan profit. Kwok menambahkan bahwa Mevas Bank dapat melayani 10,000 nasabah dengan jumlah 20 staff service representatives (Greenberg, 2001, p.1)

Menurut Ingold (2002, pp.19-20), CRM sangat cocok untuk perusahaan asuransi dimana perusahaan dapat memberikan layanan yang sifatnya personal kepada pelanggannya dengan memberikan kesempatan pada agen-agennya untuk memberikan nilai layanan yang sesuai dengan kebutuhan masingmasing pelanggannya. Di sisi lain pelanggan juga mempunyai banyak pilihan untuk berinteraksi dengan perusahaan asuransi baik para agen, secara on line (melalui website) atau langsung datang pada perusahaan.

ING Group NV di Amerika juga menggunakan CRM dengan meningkatkan pelatihan dan motivasi pada karyawannya. Menurut Dave Lewis, Kepala Bagian Marketing and Technology, 
seringkali orang menciptakan teknologi canggih tetapi mereka melupakan orang-orang yang membuat teknologi itu menjadi berbeda (Costanzo, 2003, p.8). Teknologi yang canggih tidak akan mempunyai arti jika orangorang yang mengoperasikan teknologi itu tidak dapat memberikan layanan yang berbeda karena dengan perbedaan inilah yang menjadi keunggulan bersaing sebuah perusahaan.

Di Indonesia sendiri sudah banyak perusahaan yang menerapkan CRM mulai dari industri perbankan seperti BCA (www.klickbca.com), operator selular XL (www.xl.co.id), industri makanan dan minuman Nestle (www.id.nestle.com). Melalui website BCA ini, pelanggan dapat mengakses data yang diperlukan, misalnya produk perbankan, transaksi nilai jual beli valuta asing, dll. Sedangkan di website XL, pelanggan dapat mengakses produk dan layanan celular mobile telephone. Yang terakhir melalui website Nestle, pelanggan dapat memperoleh informasi produk terbaru Nestle dan bergabung dalam kolom 'Sahabat Nestle' sebagai sarana untuk menjalin hubungan antara perusahaan dengan pelanggan.

Contoh lainnya adalah penerapan CRM di dunia pendidikan yaitu Universitas Kristen Petra, Surabaya. Melalui website Universitas Kristen Petra/UKP (www.petra.ac.id), pelanggan dapat mengakses berbagai informasi secara on line. Untuk kalangan eksternal, calon mahasiswa dapat memperoleh informasi mengenai fakultas dan jurusan yang ada di UKP serta status akreditasinya, agenda universitas seperti penerimaan mahasiswa baru, kegiatan intern dan ekstern universitas. Selain itu mereka juga dapat mengakses pengumuman penerimaan mahasiswa baru secara on line ataupun melalui telpon serta tak perlu datang berduyun-duyun ke UKP dan membuat kepadatan di J1. Siwalankerto. Data perpustakaan seperti buku-buku koleksi dan tandon, jurnal, tugas akhir juga ada di website ini. Mahasiswa juga dapat melakukan perwalian dan melihat data Kartu Rencana Studi/ KRS, Kartu Hasil Studi/ KHS, kredit point melalui internet. Sedangkan untuk kalangan internal, pejabat, dosen dan karyawan mempunyai wadah untuk berkomunikasi melalui email groups (petrastaff). Di sini mereka bisa melakukan komunikasi internal dua arah antar staf pengajar maupun pendukung dan pejabat yang bersangkutan secara on line. Dosen wali juga dapat mengakses portfolio mahasiswa dan berkomunikasi melalui web ini. 


\section{KESIMPULAN}

CRM merupakan hal penting yang perlu diperhatikan oleh perusahaan yang siap bersaing menuju era globalisasi. Perusahaan harus mampu mengakomodasi keinginan stakeholder dan shareholder nya jika ingin berkembang. Kesuksesan dan kegagalan perusahaan tergantung pada kemampuannya untuk menjalin hubungan yang harmonis dengan pelanggannya. Untuk mewujudkan dan menjalin hubungan yang selaras ini perusahaan dapat memanfaatkan IT-Based program dan software-software terkait yang mampu membantu perusahaan dalam mewujudkan efisiensi dan efektivitas kinerja perusahaan.

Aplikasi CRM dapat digunakan oleh perusahaan manufaktur dan jasa. Yang perlu dipertimbangkan bagi perusahaan adalah memilih aplikasi software yang tepat dan sesuai dengan yang diperlukan. Kunci keberhasilan CRM adalah memahami keseluruhan jalinan/hubungan kerja sama yang terjadi di dalam organisasi/perusahaan, baik yang bersifat intern maupun ekstern dengan memanfaatkan IT-Based program dan software.

Program dan software ini harus mampu memberikan kemudahan dan keuntungan pada kedua belah pihak. Bagi pelanggan, program dan software ini sebaiknya mudah digunakan, sangat efektif dan efisien serta dapat dipakai untuk melacak hal-hal yang berkaitan dengan customer relationship. Di lain pihak, pada saat yang sama, perusahaan juga memperoleh manfaat untuk meningkatkan efisiensi dan produktivitas perusahaan serta memberikan layanan dan pengalaman yang konsisten bagi pelanggannya melalui berbagai sarana dan media yang bisa dipilih oleh para penggunanya. Dengan demikian akan tercipta value chain yang harmonis dalam jangka panjang.

\section{DAFTAR PUSTAKA}

Cannon, Joseph P., Perreault, William D., McCarthy,

E. Jerome, 2008, Basic Marketing: A GlobalManagerial Approach, sixteenth edition, McGraw-Hill/ Irwin, New York, N.Y. 10020

Costanzo, Chris, 2003, "Moving Focus of CRM Efforts From Software to Employees", American Banker, New

York, N.Y.: Jun 18, 2003, Vol. 168, 1ss. 116, p.8 <http://proquest.umi. com/pqdweb?did=348451001\&sid=5\&Fmt=3\&clientId=72459\&RQT=309\&=PQD>

Freeman, Phillip \& Seddon, Peter, Benefits from CRM-Based Work Systems. <http://csrc.lse.ac. uk/asp/aspecis/20050161.pdf >

Greenberg, Ilan, 2001, “Special Report : E-Business in Asia : Customer driven”, Asiaweek, Hong Kong: Oct 5, 2001, p.1 http:/proquest.umi. $\quad$ com/pqdweb did=85034293\&sid=5\&Fmt=3\& clientId=72459\&RQT=309\&VName=PQD>

Ingold, Christine, 2002, “CRM Software Evolving for All Users”, National Underwriter, Erlanger, Mar 18, 2002, Vol. 106, lss. 11, p. 19-20 
Jones, Jennifer \& Trott, Bob, 2001, 'Getting personal on multiple CRM channels", InfoWorld, San Mateo: May 7, 2001, Vol 23, lss.19, p.33

Martin, E.W., Brown, C.V., DeHayes, D.W., Hoffer, J.A., Perkins, W.C., 2005, “Customer Relationship Management", Managing Information Technology ( $5^{\text {th }}$ ed.), Pearson Prentice Hall, pp. 194-196

O’Brien, James A., 2002, “Customer Relationship Management”, Management Information Systems: Managing Information Technology in the E-Business Enterprise ( $5^{\text {th }}$ ed.), McGrawHill Higher Education, pp.128-131.

Siebel CRM based on Siebel eBusiness Applications from Aspective, <http://www.aspective.com/ Solutions/SiebelCRM/Index.aspx>

Whitaker, Tyler, 2005, "Streamline customer contact", Landscape Management, Cleveland: Apr 2005, Vol. 44, 1ss. 4, p.50 <http://proquest. umi.com/pqdweb?did=825769871\&sid=5\&F mt=4\&clientId=72459\&RQT=309\&VName= PQD> 